\title{
Analisis Cemaran DNA Tikus pada Bakso Daging Sapi yang Beredar di Makassar dengan Metode Polymerase Chain Reaction (PCR)
}

\section{(Analysis of Rat DNA Contamination on Beef Meatballs Circulating in Makassar by Polymerase Chain Reaction (PCR) Method)}

\author{
Article Info: \\ Received: 03 March 2019 \\ in revised form: 23 March 2019 \\ Accepted: 31 March 2019 \\ Available Online: 31 March 2019

\section{Keywords:} \\ Rat meat \\ Beef meatballs \\ DNA \\ ND1 \\ Polymerase Chain Reaction
}

Aminah, Ristieyen Ramadini, Tadjuddin Naid

Fakultas Farmasi,Universitas Muslim Indonesia, Makassar, Indonesia

Corresponding Author:

Aminah

FakultasFarmasi

Universitas Muslim Indonesia

Makassar

Indonesia

Email:

aminah.aminah@umi.ac.id

\begin{abstract}
Analysis of rat DNA contamination in meatball meat circulating in Makassar by PCR (Polymerase Chain Reaction) method has been carried out. In this study, a polymerase chain reaction method will be developed to analyze the presence of rat meat contamination in beef meatballs. There are three stages in the PCR amplification process carried out with 30 cycles, which are $95^{\circ} \mathrm{C}$ temperature denaturation, $51^{\circ} \mathrm{C}$ attachment, and $72^{\circ} \mathrm{C}$ extension. DNA analysis included agarose gel electrophoresis, measurement of concentration and purification, and analysis of rat DNA using PCR. The results of PCR amplification using mouse-specific primers namely primary ND1 (NADH dehydrogenase 1) showed no bands seen in UV light. So that it can be proven that beef meatball samples in the Makassar region did not contain rat DNA.
\end{abstract}




\begin{abstract}
ABSTRAK
Analisis cemaran DNA tikus pada daging bakso yang beredar di Makassar dengan metode PCR (Polymerase Chain Reaction) telah dilakukan. Pada penelitian ini, akan dikembangkan metode polymerase chain reaction untuk menganalisis adanya cemaran daging tikus dalam bakso sapi. Ada tiga tahapan dalam proses amplifikasi PCR yang dilakukan dengan 30 siklus, yaitu denaturasi suhu $95^{\circ} \mathrm{C}$, penempelan $51^{\circ} \mathrm{C}$, dan perpanjangan $72^{\circ} \mathrm{C}$. Analisis DNA meliputi elektroforesis gel agarosa, pengukuran konsentrasi dan pemurnian, serta analisis DNA Tikus menggunakan PCR. Hasil amplifikasi PCR menggunakan primer spesifik tikus yaitu primer ND1( NADH dehydrogenase 1) menunjukkan tidak ada pita terlihat dalam cahaya UV, sehingga dapat dibuktikan bahwa sampel bakso sapi di wilayah Makassar tidak mengandung DNA tikus.
\end{abstract}

Kata Kunci : Daging tikus, Bakso sapi, DNA, ND1, Polymerase Chain Reaction.

\section{PENDAHULUAN}

Makanan adalah kebutuhan pokok manusia yang secara langsung berperan meningkatkan kesehatan sehingga mampu melakukan kegiatan sehari-hari secara baik. Untuk itulah keamanan makanan menjadi sangat penting agar tidak menimbulkan gangguan kesehatan. Tetapi belakangan ini banyak makanan yang beredar di masyarakat tidak terjamin lagi keamanannya (Agustina, 2010).

Identifikasi spesies hewan ditambahkan ke produk daging olahan adalah perhatian konstan, baik bagi konsumen maupun pihak yang berwenang (Ballin, 2010). Tujuannya adalah untuk mengotentikasi identitas standar produk yang terkait dengan labelnya yang benar, sehingga melindungi konsumen dari kemungkinan kehadiran dari jenis daging yang tidak diketahui dan tidak diinginkan. Namun produk daging adalah makanan paling banyak tunduk pada kecurangan karena kesulitan dalam pengukuran dan manfaat ekonomi pengolahannya terutama dalam produk akhir (Arslan et al, 2006).

Metode yang kini terkenal sangat akurat, cepat, mudah digunakan, dan dapat menentukan spesies asal pangan yakni metode Polymerase Chain Reaction (PCR). Selain itu, teknik PCR ini dapat dilakukan meski sampel yang digunakan berjumlah sedikit ataupun berukuran sangat kecil. Deoxyribo nucleic acid (DNA) yang berada pada sampel kemudian dapat dilipat gandakan jumlahnya dan hasilnya dilihat sebagai pita yang jelas (Arslan et al, 2006).
Penggunaan teknik Polymerase Chain Reaction (PCR) pada kasus pemalsuan pangan pernah dilakukan pada pendeteksian daging tikus, kucing, anjing, babi, ayam, sapi, domba dewasa dan kuda, baik dalam bentuk olahan maupun produk pangan (Martin et al, 2007).

Polymerase Chain Reaction (PCR) adalah suatu teknik sintesis dan amplifikasi DNA secara in vitro. Teknik ini pertama kali dikembangkan oleh Karry Mullis pada tahun 1985. Teknik Polymerase Chain Reaction (PCR) dapat digunakan untuk mengamplifikasi segmen DNA dalam jumlah jutaan kali hanya dalam beberapa jam. Dengan diketemukannya teknik Polymerase Chain Reaction (PCR) di samping juga teknik-teknik lain seperti sekuensing DNA, telah proses Polymerase Chain Reaction (PCR) melibatkan beberapa tahap yaitu: (1) pra-denaturasi DNA templat; (2) denaturasi DNA templat; (3) penempelan primer pada templat (annealing); (4) pemanjangan primer (extension) dan (5) pemantapan (post extension). Tahap (2) sampai dengan (4) merupakan tahapan berulang (siklus), di mana pada setiap siklus terjadi duplikasi jumlah DNA. Proses PCR secara umum berlangsung dalam tiga tahap, yakni tahap denaturasi, tahap penempelan (annealing), dan tahap pemanjangan (extension) (Handoyo et al, 2000).

PCR memiliki beberapa keunggulan, diantaranya dapat memperbanyak DNA pada bagian yang spesifik sesuai yang diharapkan, memiliki sensitivitas tinggi, dapat digunakan untuk melakukan pengujian hingga manipulasi DNA, mampu memberikan hasil 
dalam waktu singkat, dapat digunakan untuk mendeteksi sampel yang terkontaminasi maupun menyeleksi sampel negatif, dapat mengidentifikasi organisme secara mendetail hingga tingkat spesies bahkan serotipe yang bahkan tidak dapat dilakukan menggunakan sistem konvensional, dapat bekerja pada materi genetik dari berbagai sel, serta dapat dilakukan pada sampel yang berupa campuran kompleks. Namun demikian, PCR juga memiliki beberapa kelemahan, diantaranya DNA sel bakteri yang mati ikut terdeteksi pula (Prayoga et al, 2014). Oleh karena itu, metode PCR ini telah dilakukan untuk mengidentifikasi adanya cemaran DNA tikus pada bakso sapi yang beredar di Kota Makassar

\section{METODE PENELITIAN}

\section{Alat dan Bahan}

Alat yang digunakan pada penelitian ini adalah gel agarose (CBS Scientific), microwave (Panasonic NNST324M), mikropipet, tube eppendrotf, sentrifuge sorvall legend micro 17R (Thermo Scientific, USA), translaminator (IVA), neraca analitik (Kern ABT 220 5DM), PCR CFX 96 (Biorad, USA), shaker EFM 60 (OSK, Seiwariko CO,Ltd), spektrofotometer UV-Vis (Thermo Scientefic), vortex (Ika Genius 3), dan waterbath (Memert).

Bahan yang digunakan adalah daging sapi, daging tikus (Gambar 1) dan sampel bakso sapi yang diperoleh dari lima pedagang di kota Makassar. Sampel bakso sapi yang digunakan dapat dilihat pada Gambar 2, ultrapure agarosa (Roche), aqua bidestillata steril, aqua bebeas nuclease, dapar lisis TNE, dapar pemuat, dapar TE, dapar TBE (Roche), 1 $\mathrm{Kb}$ DNA ladder (Vivantis), etanol absolut, etanol $70 \%$, etidium bromide (EtBr), fenol, kloroform, proteinase K (Roche), RNAse (Roche) dan Enzim Dream Taq Green PCR Master Mix, Primer mitokondria gen NDI (forward primer Forward 5'CGG CAT CCT ATT ACA ACC TGC-3') (reverse primer 5'- CGG CTC CTC GTA AAG CGA A-3').
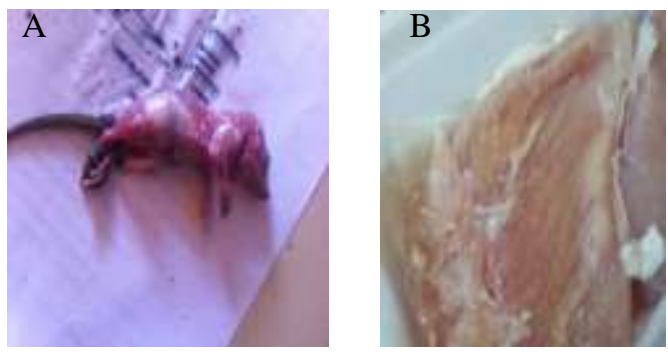

Gambar 1. (A) daging tikus , (B) daging sapi
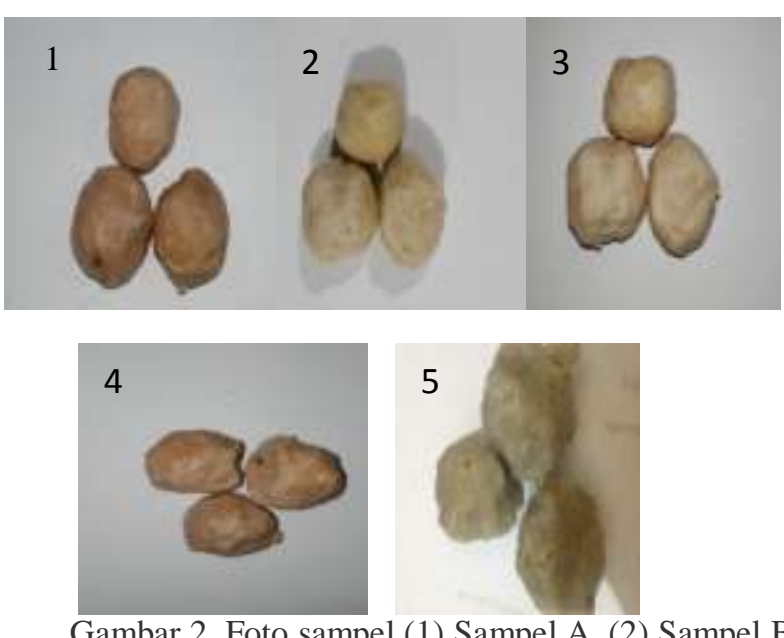

Gambar 2. Foto sampel (1) Sampel A, (2) Sampel B, (3) Sampel C, (4) Sampel D, dan (5) Sampel E

Primer yang digunakan untuk amplifikasi DNA tikus yaitu primer ND1 (NADH dehydrogenase 1) dalam Tabel 1.

Tabel 1. Sekuens primer yang digunakan

\begin{tabular}{ll}
\hline Primer & Sekuens \\
\hline Forward & 5'- CGG CAT CCT ATT ACA \\
& ACC TGC-3 ' \\
\hline Reverse & 5'- CGG CTC CTC GTA AAG \\
& CGA A-3' \\
\hline
\end{tabular}

(Primer didesain oleh Raharjo et al, 2018)

\section{Prosedur Kerja}

\section{Sterilisasi Alat dan Bahan}

Sterilisasi alat dan bahan dengan cara membungkus alat-alat, kemudian alat-alat yang tahan terhadap pemanasan disterilkan pada oven pada suhu $180^{\circ} \mathrm{C}$ selama 2 jam, sedangkan alat yang tidak tahan terhadap pemanasan disterilkan pada autoklaf dengan tekanan 1 atm selama 15 menit

\section{Preparasi sampel jaringan segar}

Jaringan/daging disiapkan dari 2 spesies (tikus dan sapi) yang telah diverifikasi spesimen jenisnya. Masing-masing daging dicuci bersih dengan air mengalir, ditiriskan lalu dicincang hingga halus dan disimpan pada suhu $-20^{\circ} \mathrm{C}$ hingga siap digunakan

\section{Preparasi sampel bakso sapi}

Sampel bakso masing-masing terdiri dari lima produk bakso sapi yang dikumpulkan di wilayah kota Makassar. Tiap sampel sebanyak $0.2 \mathrm{~g}$ diambil dari 5 titik yang tersebar pada sampel. Selanjutnya dimasukkan ke dalam tabung $2 \mathrm{~mL}$. Semua sampel 
pasaran diberi label dan disimpan pada suhu $-20^{\circ} \mathrm{C}$ hingga digunakan untuk penyiapan isolasi DNA.

\section{Tahapan Isolasi DNA (Sambrook et al. 1989) Isolasi DNA jaringan hewan}

Jaringan hewan sebanyak $0,2 \mathrm{~g}$ dimasukkan ke dalam lumpang, ditambahkan $0,5 \mathrm{~mL}$ dapar lisis, dan digerus hingga halus. Kemudian, jaringan hewan dimasukkan ke dalam tabung $2 \mathrm{~mL}$, ditambahkan 0,5 $\mathrm{mL}$ dapar lisis lalu divortex selama \pm 4 menit. Setelah itu, jaringan hewan ditambahkan $15 \mu \mathrm{L}$ Proteinase-K $(20 \mu \mathrm{g} / \mu \mathrm{L})$ divortex \pm 1 menit, kemudian diinkubasi dalam waterbath pada suhu $60^{\circ} \mathrm{C}$ selama 1 jam (setiap 15 menit dibolak-balik). Selanjutnya jaringan hewan disentrifus menggunakan mikrosentrifus dengan kecepatan 13.000 rpm selama 5 menit, lalu supernatan dipindahkan ke tube $2 \mathrm{~mL}$ baru. Supernatan ditambahkan fenol dingin 1:1, kemudian dishaker cepat \pm 30 menit. Selanjutnya, supernatan disentrifus menggunakan mikrosentrifus dengan kecepatan $13.000 \mathrm{rpm}$ selama 10 menit, lalu supernatan dipindahkan ke tube $2 \mathrm{~mL}$ baru. Kemudian Supernatan ditambahkan kloroform dingin $1: 1$, lalu dishaker lambat \pm 15 menit. Selanjutnya supernatan disentifus menggunakan sentrifus dengan kecepatan $13.000 \mathrm{rpm}$ selama 10 menit lalu dipindahkan ke tube eppendorf $1,5 \mathrm{~mL}$ baru. Kemudian supernatan ditambahkan etanol absolute dingin 1:2, dibolak-balik perlahan hingga terbentuk benang, dan apabila tidak terbentuk benang, disimpan pada suhu $-80^{\circ} \mathrm{C}$ selama $1 \mathrm{jam}$. Supernatan kemudian disentrifus menggunakan mikrosentrifus dengan kecepatan $13.000 \mathrm{rpm}$ selama 15 menit, supernatan dibuang dan endapan ditambahkan $0,5 \mathrm{~mL}$ etanol 70\%. Kemudian endapan disentrifus menggunakan mikrosentrifus dengan kecepatan 13.000 rpm selama 10 menit, supernatan dibuang dan endapan dikeringkan \pm 2 jam. Setelah endapan kering, ditambahkan $40 \mu \mathrm{L}$ dapar TE, disimpan pada suhu $4^{\circ} \mathrm{C}$ semalam. Kemudian endapan kering ditambahkan $3 \mu \mathrm{L}$ RNase $(20 \mu \mathrm{g} / \mu \mathrm{L})$, diinkubasi dalam waterbath suhu $37^{\circ} \mathrm{C}$ selama 1 jam. Lalu disimpan pada suhu $-20^{\circ} \mathrm{C}$ sampai siap digunakan.

\section{Isolasi DNA bakso sapi}

Jaringan sebanyak $0,2 \mathrm{~g}$ dimasukkan ke dalam lumpang, ditambahkan $0,5 \mathrm{~mL}$ dapar lisis, dan digerus hingga halus. Kemudian, jaringan hewan dimasukkan ke dalam tabung $2 \mathrm{~mL}$, ditambahkan 0,5 $\mathrm{mL}$ dapar lisis lalu divortex selama \pm 4 menit. Setelah itu, jaringan hewan ditambahkan $15 \mu \mathrm{L}$ Proteinase-K $(20 \mu \mathrm{g} / \mu \mathrm{L})$ divortex \pm 1 menit, kemudian diinkubasi dalam waterbath pada suhu $60^{\circ} \mathrm{C}$ selama 1 jam (setiap 15 menit dibolak-balik). Selanjutnya jaringan hewan disentrifus menggunakan mikrosentrifus dengan kecepatan 13.000 rpm selama 5 menit, lalu supernatan dipindahkan ke tube $2 \mathrm{~mL}$ baru. Supernatan ditambahkan fenol dingin 1:1, kemudian dishaker cepat \pm 30 menit. Selanjutnya, supernatan disentrifus menggunakan mikrosentrifus dengan kecepatan 13.000 rpm selama 10 menit, lalu supernatan dipindahkan ke tube $2 \mathrm{~mL}$ baru. Kemudian Supernatan ditambahkan kloroform dingin $1: 1$, lalu dishaker lambat \pm 15 menit. Selanjutnya supernatan disentifus menggunakan sentrifus dengan kecepatan $13.000 \mathrm{rpm}$ selama 10 menit lalu dipindahkan ke tube eppendorf $1,5 \mathrm{~mL}$ baru. Kemudian supernatan ditambahkan etanol absolute dingin 1:2, dibolak-balik perlahan hingga terbentuk benang, dan apabila tidak terbentuk benang, disimpan pada suhu $-80^{\circ} \mathrm{C}$ selama 1 jam. Supernatan kemudian disentrifus menggunakan mikrosentrifus dengan kecepatan $13.000 \mathrm{rpm}$ selama 15 menit, supernatan dibuang dan endapan ditambahkan $0,5 \mathrm{~mL}$ etanol 70\%. Kemudian endapan disentrifus menggunakan mikrosentrifus dengan kecepatan $13.000 \mathrm{rpm}$ selama 10 menit, supernatan dibuang dan endapan dikeringkan \pm 2 jam. Setelah endapan kering, ditambahkan $40 \mu \mathrm{L}$ dapar TE, disimpan pada suhu $4^{\circ} \mathrm{C}$ semalam. Kemudian endapan kering ditambahkan $3 \mu \mathrm{L}$ RNase $(20 \mu \mathrm{g} / \mu \mathrm{L})$, diinkubasi dalam waterbath suhu $37^{\circ} \mathrm{C}$ selama 1 jam. Lalu disimpan pada suhu $-20^{\circ} \mathrm{C}$ sampai siap digunakan.

\section{Analisis DNA (Sambrook et al. 1989) Elektroforesis gel agarosa}

Isolasi DNA sebanyak $10 \mu \mathrm{L}$ yang telah ditambahkan $2 \mu \mathrm{L}$ dapar pemuat, dianalisis secara elektroforesis pada gel agarosa $0,8 \%$ menggunakan dapar TBE dan telah diwarnai dengan etidium bromide (untuk $1 \mathrm{~L}$ larutan dapar terdiri dari 10,8 $\mathrm{g}$ Tris base, 5,5 $\mathrm{g}$ asam borat, $4 \mathrm{~mL}$ EDTA $0,5 \mathrm{M} \mathrm{pH} \mathrm{8)} \mathrm{dengan} \mathrm{arus} 90 \mathrm{~V}$ selama 60 menit. Gel agarosa hasil elektroforesis tersebut divisualisasi dengan UV-transluminator dan gambar didokumentasikan.

\section{Pengukuran konsentrasi dan kemurnian DNA}

DNA sebanyak $2 \mu \mathrm{L}$ ditambahkan $998 \mu \mathrm{L}$ aqua bidestillata steril (dalam tube), dihomogenkan. Kemudian diukur dengan spektrofotometer UV pada panjang gelombang 260 dan 280nm. Konsentrasi DNA hasil isolasi dihitung dari $\mathrm{A}_{260}$ dikalikan faktor pengencerannya dan konstanta serapan DNA (serapan DNA murni pada panjang gelombang 260 
nm dengan 1 absorbansi unit mengandung $50 \mu \mathrm{g} / \mathrm{mL}$ DNA)

\begin{abstract}
Analisis DNA Tikus dengan PCR
Amplifikasi dengan PCR dilakukan dengan penggunaan campuran reaksi $20 \mu \mathrm{L}$ yang terdiri dari $2 \mu \mathrm{L}(50 \mathrm{ng})$ isolate DNA , $1 \mu \mathrm{L}$ masing-masing primer forward dan reverse $(500 \mathrm{~nm})$, dan $6 \mu \mathrm{L}$ aqua bebas nuclease. Pengujian mengikuti kondisi suhu $95^{\circ} \mathrm{C}$ untuk aktivasi enzim/ denaturasi awal, selanjutnya diikuti dengan 30 siklus ; $95^{\circ} \mathrm{C}$ selama 5 detik (tahapan denaturasi), $62^{\circ} \mathrm{C}$ selama 10 detik (tahap hibridisasi/ annealing), dan $72^{\circ} \mathrm{C}$ selama 10 detik (tahap lanjutan/ extension).
\end{abstract}

\section{HASIL DAN PEMBAHASAN}

Polymerase Chain Reaction (PCR) adalah adalah suatu metode enzimatis untuk amplifikasi DNA dengan cara in vitro. Pada proses PCR diperlukan beberapa komponen utama, yaitu DNA cetakan, Oligonukleotida primer, Deoksiribonukelotida trifosfat (dNTP), Enzim DNA Polimerase, dan Komponen pendukung lain adalah senyawa buffer. Metode PCR (Polymerase Chain Reaction) sekarang sudah umum dan sering digunakan teknik yang sangat diperlukan yang digunakan dalam medis dan laboratorium penelitian biologi untuk berbagai aplikasi. Reaksi berantai polimerase adalah teknik kuat yang dengan cepat menjadi satu teknik yang paling banyak digunakan dalam molekul biologi karena cepat, dansederhana (Gaurav, 2012).

Pada produk makanan olahan tertentu terbuat dari daging, akhir -akhir ini tidak jarang ditayangkan di media masa elektronik akan adanya campuran produk makanan olahan untuk konsumsi manusia yang tercampur dengan daging dari jenis (spesies) lain selain bahan utamanya berupa daging sapi misalnya. Campuran tersebut dapat berupa daging tikus.

Pendeteksian DNA daging tikus pada sampel bakso sapi yang beredar di kota Makassar dengan menggunakan daging tikus sebagai kontrol positif dan bakso sapi sebagai kontrol negatif serta menggunakan 5 jenis bakso sapi yang berada di kota Makassar dengan merek yang berbeda yaitu bakso dewi sinta, bakso mba nur, bakso tanpa nama, bakso nikmat dan bakso joko. Pendeteksian dilakukan dengan menggunakan metode PCR (Polymerase Chain Reaction). Metode analisis pencemaran daging tikus pada produk makanan bakso dan sampel daging telah dilakukan dengan analisis molekuler menggunakan teknik PCR (Polymerase Chain Reaction).

Tahap pertama isolasi DNA dilakukan menggunakan lysis buffer, bahan lysis buffer terdiri dari Tris $\mathrm{HCl}$ $\mathrm{pH} \mathrm{8,} \mathrm{EDTA} \mathrm{pH} \mathrm{8,} \mathrm{NaCl}$ dan SDS, penghancuran membran sel (lisis) dengan menambahkan detergen untuk membuat sel menjadi rusak dan mengeluarkan komponen- komponennya yaitu protein, lipid, karbohidrat, DNA dan RNA, detergen yang biasa digunakan yaitu SDS. SDS (Sodium Dodecyl Sulfate) adalah detergen yang mempunyai muatan negatif yang sangat besar sehingga SDS akan mengikat muatan positif dari protein dan dengan demikian mengakibatkan pergerakan protein kearah elektroda positif . Tris adalah dapar yang di gunakan untuk menjaga kestabilan pH, EDTA (Etylene diamine tetra acetic acid) berfungsi sebagai penghelat menyebabkan membran sel tidak stabil karena mengandung ion pengkelat $\mathrm{Mg}^{+2}$ yang di kombinasi dengan enzim pendegradasi membrane sel yaitu enzim lisozim, dan $\mathrm{NaCl}$ berfungsi membantu pengendapan protein karena adanya fenomena salting-out.

Sampel diiinkubasi dalam waterbath pada suhu $55^{\circ} \mathrm{C}$ selama 1 jam untuk menginaktifasi enzim yang mendegradasi DNA. Proses degradasi protein diperlukan kondisi yang optimal pada suhu $50-55^{\circ} \mathrm{C}$ dan ditambahkan proteinase $\mathrm{K}$ sebagai reagen pelisis supaya komponen DNA dalam sitoplasma sel bisa keluar dan diisolasi. Selanjutnya dilakukan sentrifugasi. Prinsip utama dari sentrifugasi adalah memisahkan substansi berdasarkan berat jenis molekul sehingga di peroleh DNA dengan kemurnian yang cukup tinggi dan dapat dilihat dari penampakan hasil elektroforesis yang baik. Pada tahap purifikasi supernatan dari hasil sentrifuge ditambahkan fenol dingin (1:1) untuk mengendapkan komponen protein lain yang tidak dikehendaki. Ditambahkan kloroform karena kloroform merupakan pelarut organik yang dapat mendenaturasi dan memisahkan kontaminasi protein. Tahap dengan menggunakan etanol $70 \%$ untuk membersihkan DNA dari zat - zat pengotor. Ditambahkan RNase karena RNase merupakan endoribonuklease yang secara khusus mendegradasi $\mathrm{C}$ dan U pada untai tunggal RNA. RNase memotong rantai fosfodiester antara 5' - ribosa pada nukleotida dan kelompok fosfat pada 3'- ribosa pirimidin yang saling berdekatan. 
Hasil isolasi kemudiaan di analisis dengan menggunakan elektroforesis. Elektroforesis pada dasarnya bekerja berdasarkan migrasi atau perpindahan partikel-partikel bermuatan dalam lingkungan yang memiliki medan listrik dan kemudian terpisahkan oleh gel elektroforesis. Semua molekul atau fragmen DNA bermuatan negatif, sehingga fragmen DNA akan bergerak menuju kutub positif (anoda) dengan perpindahan yang sama dalam medan listrik.

Dalam pembuatan gel agarosa di tambahkan dengan etidium bromide yang berfungsi untuk visualisasi gel. Menurut Gaffar (2007) etidium bromide akan masuk di antara ikatan hidrogen pada DNA, sehingga pita fragmen DNA akan kelihatan dibawah lampu UV. Gel agarosa yang telah memadat diberi larutan TBE buffer $1 \mathrm{x}$ hingga terendam. Kemudian dilakukan proses loading sampel ke dalam sumur-sumur yang terdapat pada gel dan dilakukan elektroforesis.

Setelah proses elektroforesis selesai, gel agarosa diamati dibawah sinar ultraviolet yang akan terbentuk pita - pita berwarna kuning-merah.

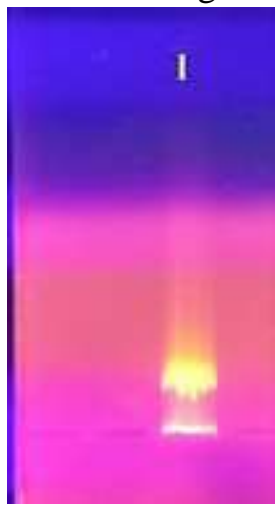

Gambar 3. Hasil elektroforesis DNA daging sapi segar (1)

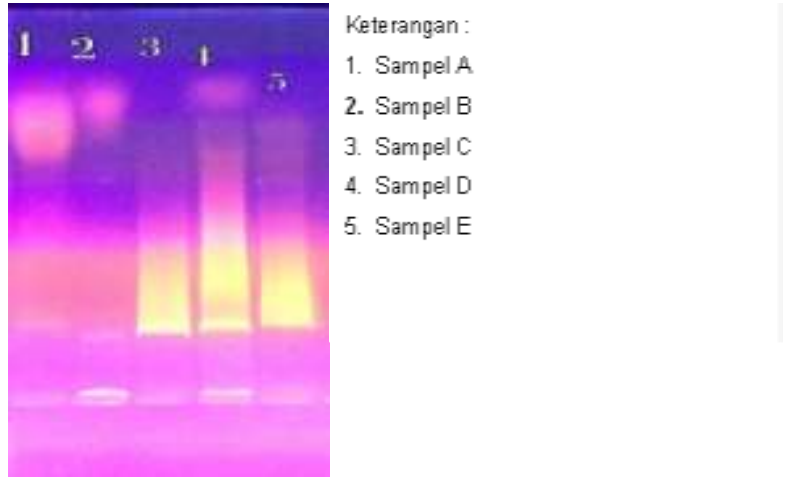

Gambar 4. Hasil elektroforesis sampel bakso Sapi

Setelah dilakukan elektroforesis selanjutnya dilakukan pengukuran konsentrasi dan kemurniaan dengan menggunakan spektrofotometer UV-Vis dengan menggunakan panjang gelombang $\mathrm{A}_{260}$ dan $\mathrm{A}_{280}$. Panjang gelombang $260 \mathrm{~nm}$ digunakan dalam penelitian ini, karena pada panjang gelombang tersebut daya serapan sinar oleh nukleotida maksimal. Sedangkan penyerapan maksimal oleh protein dicapai pada panjang gelombang $280 \mathrm{~nm}$ (Tenriulo et al, 2001). Hasil pengujian menunjukkan adanya DNA daging sapi pada masing-masing sampel bakso sapi (Gambar 3 dan 4).

Tabel 2. Hasil uji kuantitatif spektrofotometer UVVIS isolat DNA daging segar

NO. Sampel Kemurnian $\left(A_{260} / A_{280}\right)$ Konsentrasi $(\mu \mathrm{g} / \mathrm{mL})$

$\begin{array}{llrr}1 & \text { Sapi } & 2,066 & 775 \\ 2 & \text { Tikus } & 1,594 & 2750\end{array}$

Tabel 3. hasil uji kuantitatif spektrofotometer UVVIS isolat sampel bakso sapi

\begin{tabular}{lccc}
\hline NO. Kode Isolat & Kemurnian $\left(\mathbf{A}_{\mathbf{2 6 0}} / \mathbf{A}_{\mathbf{2 8 0}}\right)$ & Konsentrasi $(\boldsymbol{\mu g} / \mathbf{m L})$ \\
\hline 1 & $\mathrm{~F}_{9}$ & 2 & 100 \\
2 & $\mathrm{E}_{7}$ & 1.909 & 525 \\
3 & $\mathrm{I}_{5}$ & 1.658 & 1.700 \\
4 & $\mathrm{G}_{10}$ & 1.705 & 725 \\
5 & $\mathrm{H}_{10}$ & 1.5 & 675 \\
\hline \multicolumn{2}{l}{ Keterangan: (1) Bakso Nikmat $\left(\mathrm{E}_{7}\right),(2)$ Bakso Tanpa Nama $\left(\mathrm{I}_{5}\right),\left(\right.$ (3) Bakso Joko $\left(\mathrm{G}_{10}\right)}$,
\end{tabular}

(4) Bakso Mba Nur $\left(F_{9}\right)$, (5) Bakso Dewi Sinta $\left(\mathrm{H}_{10}\right)$.

Pada tabel 2 sampel daging sapi segar memiliki konsentrasi $775 \mu \mathrm{g} / \mathrm{mL}$ dan tikus memiliki konsentrasi $2750 \mu \mathrm{g} / \mathrm{mL}$. Pada tabel 3 masing masing sampel bakso sapi yang di beli dari berbagai pasar tradisional berkisaran konsentrasi 100-1700 $\mu \mathrm{g} / \mathrm{mL}$, sedangkan untuk nilai kemurnian yang diperoleh dari masing - masing sampel yaitu 1.5-2. Sampel di bawah nilai kemurnian 1,8, masing masing ada 3 sampel yaitu sampel $\mathrm{H}_{10} 1.5$, sampel $\mathrm{G}_{10}$ 1.705, dan sampel $\mathrm{I}_{5} 1.658$ yang artinya terkandung zat - zat pengotor seperti protein dan fenol.

Proses amplifikasi DNA mitokondria menggunakan alat Polymerse Chain Reaction (PCR) . Pada MtDNA mempunyai jumlah cetakan yang tinggi yaitu sekitar 1000-10000 cetakan, sehingga mtDNA dapat digunakan untuk analisis sampel dengan walaupun jumlah DNA yang sangat terbatas. Untuk melakukan proses PCR (Polymerase Chain Reaction) masing masing disiapkan campuran reaksi total PCR sebanyak $20 \mu \mathrm{L}$ yang terdiri dari $\mathrm{ddH}_{2} \mathrm{O} 6 \mu \mathrm{L}$, enzim dream Taq green PCR master mix $10 \mu \mathrm{L}$, masing - 
masing $1 \mu \mathrm{L}$ primer forward dan reverse, serta DNA sampel $2 \mu \mathrm{L}$ masukkan kedalam tabung effendorf lalu di PCR. Pada proses ini amplifikasi dilakukan dengan 30 siklus karena dapat menghasilkan amplicon yang lebih jelas dan tebal. Ada tiga tahapan penting dalam proses PCR yang selalu terulang dalam 30 siklus yang pertama denaturasi, annealing (penempelan primer), extention (pemanjangan primer). Pada tahap denaturasi terjadi proses pembukaan DNA untai ganda menjadi DNA untai tunggal biasanya berlangsung selama 3 menit pada suhu $95^{\circ} \mathrm{C}$, adapun waktu denaturasi yang terlalu lama dapat mengurangi aktifitas enzim Taq green polymerase. Enzim DNA polimerase, yaitu enzim yang melakukan katalisis reaksi sintesis rantai DNA. Enzim ini tahan terhadap pemanasan berulang-ulang yang akan membantu melepaskan ikatan primer yang tidak tepat dan meluruskan wilayah yang mempunyai struktur sekunder. Tahap kedua annealing (penempelan primer), primer yang di gunakan yaitu primer ND1 karena dapat mendeteksi kontaminasi daging tikus pada daging lain sampai level kontaminasi $1 \%$. Waktu annealing yang biasa digunakan dalam PCR adalah $30-45$ detik. Semakin panjang ukuran primer, semakin tinggi temperaturnya. Temperatur penempelan DNA yang digunakan adalah $51^{\circ} \mathrm{C}$ karena suhu annealing harus $5^{\circ} \mathrm{C}$ di bawah $t m$ (melting temperature) yang sebenarnya pada primer yang digunakan. Tahap yang terakhir extention (pemanjangan primer) selama tahap ini enzim green Taq polymerase memulai aktivitasnya memperpanjang DNA primer dari ujung 3'. Kecepatan penyusunan nukleotida oleh enzim tersebut pada suhu $72^{\circ} \mathrm{C}$ diperkirakan $35-100$ nukleotida/detik, bergantung pada buffer, $\mathrm{pH}$, konsentrasi garam dan molekul DNA target. Dengan demikian untuk produk PCR dengan panjang 2000 pasang basa, waktu 1 menit sudah lebih dari cukup untuk tahap perpanjangan primer ini. Biasanya di akhir siklus PCR waktu yang digunakan untuk tahap ini diperpanjang sampai 5 menit sehingga seluruh produk PCR diharapkan terbentuk DNA untaian ganda.

Produk PCR (Polymerase Chain Reaction) dapat diidentifikasi melalui ukurannya dengan menggunakan elektroforesis gel agarosa. Pada gambar 5, daging tikus terdapat pita yang tebal dan jelas pada hasil elektroforesis setelah di PCR (Polymerase Chain Reaction). Sedangkan tidak

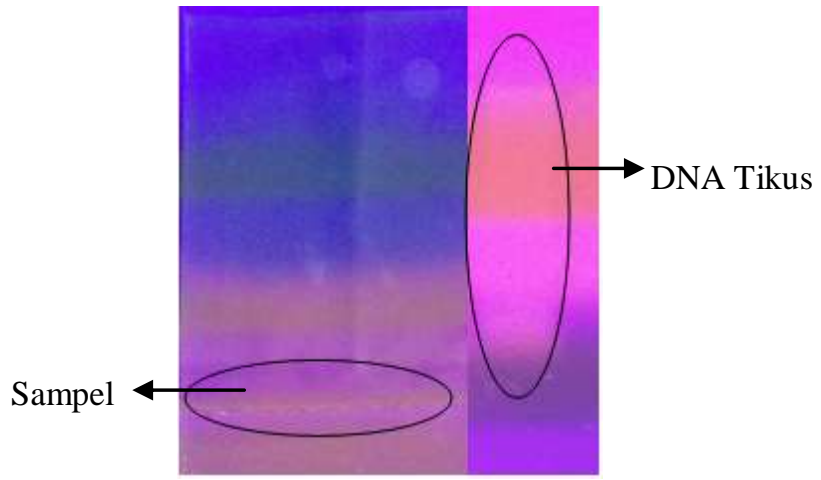

Gambar 5. Hasil elektroforesis daging tikus setelah di PCR (Polymerase Chain Reaction) menggunakan primer ND1

terlihat pita yang muncul pada bakso sapi yang tidak berlogo MUI yaitu sampel A, sampel B, sampel C, sampel D, sampel E. Hal ini menunjukkan bahwa primer ND1 (NADH dehydrogenase 1) yang digunakan dapat mengamplifikasi DNA daging tikus yang terdapat pada pembanding maupun sampel yang telah diujikan. Tidak adanya pita yang terlihat pada kelima sampel bakso sapi menunjukkan bahwa dari sampel tersebut tidak mengandung DNA daging tikus, sehingga layak di konsumsi khususnya bagi masyarakat muslim.

\section{KESIMPULAN}

Primer ND1 (NADH hydrogenase 1) dapat digunakan untuk menganalisis cemaran DNA tikus pada makanan yang berbahan daging. Dari hasil penelitiaan yang telah dilakukan dapat diberikan saran perlu adanya monitoring terhadap produk asal hewan dan turunannya terhadap kemungkinan adanya kasus-kasus pencampuran daging yang tidak lazim dikonsumsi.

\section{DAFTAR PUSTAKA}

Agustina, T. (2010). Kontaminasi logam berat pada makanan dan dampaknya pada kesehatan, Teknobuga, 2(2), 53-65.

Arslan, A., O. I. Ilhak, and Calicioglu, M. (2006). Effect of method of cooking on identification of heat processed beef using polymerase chain reaction (PCR) technique. Meat Science. 72, 326-330.

Ballin, N.Z. (2010). Authentication of meat and meat products. Meat Science, 3, 577-587. 
Gaffar, S. (2007). Buku Ajar Bioteknologi Molekul, FMIPA UNPAD, Bandung

Gaurav, S. (2012). Polymerase Chain Reaction, International Journal of Pharmacological Research, 2 (3), 98.

Handoyo, D., \& Rudiretna, A. (2000). Prinsip umum dan pelaksanaan polymerase chain reaction (PCR) [general principles and implementation of polymerase chain reaction], Unitas, 9(1), 17-29.

Martín I, García T, Fajardo V, Rojas M, Hernández PE, González I, Martín R. (2007). Technical Note : Detection of Cat, Dog, and Rat or Mouse Tissues in Food and Animal Feed Using Spesies-Specific Polymerase Chain reaction, J Anim Sci. 85(10), 2734-2739

Prayoga, W., \& Wardani, A.K. (2014). Polymerase Chain Reaction Untuk Deteksi Salmonella $s p$, Kajian Pustaka, Jurnal Pangandan Agroindustri, 3(2), 483-488.

Sambrook, J., \& Russell, D.W. (1989). Molecular Cloning: A Laboratory Manual 3rd edition, New York, Cold Spring Harbor Laboratory Press.

Raharjo, T., \& Nuryanti, I., Patria, F.P., \& Swasono, R. (2018). Mitochondrial ND-1 gene-specific primer polymerase chain reaction to determine mice contamination in meatball. International Food Research Journal, 25, 638-642.

Tenriulo, A., Suryati, E., Parenrengi, A., \& Rosmiati. (2001). Ekstraksi DNA Rumput Laut Rappaphycus alvarezil dengan metode Fenol Kloroform , Marina Chimica Acta, 2(2), 610. 